\title{
Analisis Penempatan Access Point Pada Jaringan Wireless LAN STMIK Asia Malang Menggunakan One Slope Model
}

\author{
Fransiska Sisilia Mukti ${ }^{1}$, Danang Arbian Sulistyo \\ STMIK ASIA Malang \\ ${ }^{1}$ ms.frans@asia.ac.id, ${ }^{2}$ danangarbian@gmail.com
}

\begin{abstract}
ABSTRAK.Penelitian ini bertujuan untuk menganalisis penempatan access point (AP) pada jaringan WLAN STMIK Asia Malang. Pendekatan pertama dilakukan melalui site survey, dengan tujuan yakni mendapatkan informasi yang cukup mengenai jumlah dan penempatan AP yang saat ini diaplikasikan pada gedung kampus STMIK Asia Malang. Hasil dari walktest ini akan digunakan sebagai parameter untuk perhitungan teoritis menggunakan model propagasi One Slope Model(1SM). Berdasarkan perhitungan 1SM, didapatkan jarak optimal untuk penempatan AP tidak lebih dari $13 \mathrm{~m}$ pada propagasi LOS (rentang kuat sinyal -10dB sampai dengan -20dB, pada area koridor gedung) dan jarak $6 \mathrm{~m}$ pada propagasi NLOS (rentang kuat sinyal -40dB sampai dengan $-50 \mathrm{~dB}$, pada area ruangan perkuliahan). Hasil analisis membuktikan bahwa keberadaan barrier mempengaruhi kekuatan sinyal yang diterima oleh user, sehingga penempatan perangkat WLAN, dalam hal ini AP perlu diperhatikan.
\end{abstract}

Kata Kunci: Access Point; WLAN; One Slope Model; Propagasi Indoor

\begin{abstract}
This study aims to analyze the placement of access points (AP) in the STMIK Asia Malang. The first approach is done by site survey, with the aim of getting information about number and placement of APs that are currently applied to the STMIK Asia Malang. The results of this walktest will be used as a parameter for theoretical calculations using the One Slope Model (1SM) propagation model. Based on 1SM calculation, the optimal distance for AP placement is not more than $13 \mathrm{~m}$ in LOS propagation (signal strength range around $-10 \mathrm{~dB}$ to $-20 \mathrm{~dB}$, in the corridor area of the building) and approximately $6 \mathrm{~m}$ in NLOS propagation (signal strength range around -40dB up to - $50 \mathrm{~dB}$, for the class area). The results prove that the existence of the barrier affects the signal strength that received by the user, so that the placement of WLAN devices, in this case, AP, needs to be considered.
\end{abstract}

Keywords: Access Point; WLAN; One Slope Model; Indoor Propagation

\section{PENDAHULUAN}

Penggunaan komunikasi nirkabel untuk tujuan pribadi dan komersial telah berkembang dengan begitu cepat pada beberapa dekade terakhir. Berbagai perangkat dikembangkan seiring dengan meningkatnya jumlah pengguna jaringan nirkabel, atau lebih dikenal dengan teknologi Wi-Fi (Wireless Fidelity). Teknologi Wi-Fi merupakan suatu teknologi yang menggunakan media transmisi udara (gelombang radio). Teknologi yang menggunakan standar IEEE $802.11 \mathrm{a} / \mathrm{b} / \mathrm{g}$ ini bekerja pada frekuensi $2.4 \mathrm{GHz}$, yang saat ini telah tersebar di semua tempat, seperti kantor pemerintahan, perusahaan swasta, institusi pendidikan ataupun berbagai tempat hiburan(Zrno, Simunic, \& Roboz, 2004).

Salah satu teknologi Wi-Fi yang banyak digunakan pada institusi pendidikan adalah WLAN (Wireless $L A N$ ). WLAN merupakan jenis LAN yang dibangun dengan menggunakan teknologi komunikasi wireless yang menyediakan semua fitur yang diberikan oleh jaringan LAN berkabel (wired LAN). Jika dibandingkan dengan wired LAN, WLAN memiliki beberapa keunggulan di bidang mobilitas, fleksibilitas, kecepatan jaringan, biaya yang lebih rendah, manajemen yang lebih mudah, kapabilitas pengembangan yang lebih baik dan sebagainya (Meng, He, Deng, \& Li, 2012).

Kinerja suatu jaringan Wi-Fi dapat diketahui berdasarkan level sinyal yang dapat diterima oleh pengguna, sedangkan tingkat penerimaan sinyal bergantung kepada penempatan perangkatnya, dalam hal ini adalah access point (AP). Penempatan AP merupakan salah satu permasalahan di bidang infrastruktur jaringan, karena penempatan yang kurang tepat akan berimbas terhadap ketidakseimbangan area yang dapat di-cover. Penempatan access pointyang tepat dapat memberikan coverageyang merata pada daerah yang diinginkan dengan seminimal mungkin overlapdan blank spot. Penempatan access point ini tentunya dengan memperhatikan adanya pathlossdan jumlah user yang akan dilayani sehingga dengan jumlah access pointyang seminimal mungkin dapat diperoleh coverageyang maksimal (Puspitasari \& Pulungan, 2015).

Penelitian ini dilakukan untuk menganalisis kinerja jaringan $\mathrm{Wi}-\mathrm{Fi}$ pada area kampus pusat STMIK ASIA Malang, yang terdiri atas 4 lantai dengan masing-masing lantai terdapat area perkuliahan (ruang kelas), ruang dosen dan administrative, serta laboratorium pada lantai 1 . Pengukuran penerimaan sinyal akan dilakukan pada beberapa titik di dalam gedung kampus dengan sebuah alat bantu pengukur penerimaan kuat 
sinyal Wi-Fi. Data yang sama dari hasil pengukuran tersebut akan dihitung secara teoritis menggunakan One Slope Model.

\section{LANDASAN TEORI}

\section{a) Penelitian Terkait}

Sebuah penelitian mengenai propagasi indoor untuk jaringan wireless yang beroperasi di frekuensi 2.45 GHz ISM (Industrial, Scientific and Medical) Band dilakukan oleh Valek, Zvanovec, dan Pechac (2002). Untuk merencanakan sebuah system jaringan wireless LAN (WLAN) yang bekerja pada ISM Band, dibutuhkan adanya prediksi sinyal propagasi. Skenario indoor biasanya cukup rumit karena bergantung kepada adanya perpindahan lingkungan dinamis, dalam hal ini adalah adanya pergerakan dari manusia sebagai pengguna. Sejak system WLAN menggunakan transmisi wideband, maka nilai Quality of Service (QoS) tidak lagi berpedoman kepada rata-rata kuat sinyal pada sebuah tempat, melainkan juga bergantung pada statistic fading yang dihasilkan. Oleh karena itu diperlukan adanya dua jenis pengukuran untuk area indoor. Pengukuran pertama merupakan pengukuran narrowband yang bertujuan untuk mencari parameter empiris untuk pemodelan propagasi COST231 Multi-Wall dan One-Slope Model. Model ini mengijinkan adanya prediksi terhadap rata-rata level sinyal untuk perencanaan awal cakupan area jaringan. Pengukuran kedua merupakan pengukuran wideband, yang difokuskan pada jangka panjang pengukuran tingkat daya sinyal menggunakan PCMCIA WLAN Card yang terintegrasi pada laptop. Hal ini dilakukan untuk mendapatkan nilai statistic adanya fading (penghamburan sinyal). Hasil akhir dari pengukuran ini adalah mendapatkan nilai power margin dan nilai QoS untuk implementasi system WLAN(Zrno et al., 2004).

Selanjutnya, Zvanovec, Pechac dan Klepal (2003) melakukan studi komparasi mengenai pendekatan yang dapat diterapkan dalam mendesain jaringan WLAN untuk skenario area tertutup (indoor). Pendekatan pertama disebut sebagai site survey, yakni pendekatan yang dilakukan dengan cara melakukan pengukuran secara langsung di lapangan.Tujuan utama dari pendekatan iniadalah untuk mendapatkan informasi yang cukup dalam menentukan jumlah dan penempatan access point (AP) yang tepat agar dapat menyediakan cakupan jaringan yang memadai. Hasil akhir dari pendekatan ini adalah rekomendasi perubahan posisi atau konfigurasi dari AP, atau penambahan perangkat AP. Pendekatan ini akan dilakukan secara berulang untuk menemukan solusi iteratif yang terbaik. Pendekatan kedua disebut sebagai pemodelan propagasi. Pemodelan ini dilakukan dengan menggunakan bantuan aplikasi perencanaan propagasi. Untuk scenario indoor, diperlukan adanya deskripsi secara mendetail mengenai ruangan meliputi material bangunan yang digunakan, jenis pintu, furniture yang ada di dalamnya, hingga ketebalan setiap tembok yang ada di sekitar perangkat. Informasi ini diperlukan untuk mendapatkan hasil pemodelan yang akurat dan dapat dipercaya. Selanjutnya, dilakukan analisis terhadap kelebihan dan kekurangan masing-masing pendekatan. Keuntungan utama dari pendekatan site survey adalah dapat menunjukkan performansi jaringan yang secara real, namun seringkali pengukuran dengan pendekatan ini membutuhkan waktu yang lama untuk dilakukan. Sedangkan pada pendekatan pemodelan propagasi, sebuah perencanaan penempatan perangkat dapat dilakukan tanpa harus melakukan survei secara langsung, dan prediksi propagasi dapat dihitung dan diketahui secara langsung melalui alat bantu. Namun kelemahan dari pendekatan ini adalah tidak dapat memberikan nilai performansi yang akurat karena tidak memperhitungkan faktor mobilitas pengguna(Zvanovec, Pechac, \& Klepal, 2003).

\section{b) Pathloss}

Bila dibedakan berdasarkan jenis lintasannya, propagasi gelombang radio dapat dikelompokkan menjadi dua, yaitu, lintasan line of sight (LOS) dan lintasan non line of sight (NLOS). Kedua lintasan tersebut akan mengalami rugi-rugi daya yang dikarenakan besar sinyal yang diterima oleh antena penerima merupakan penjumlah vektor darimasing-masing sinyal pada lintasan jamak yang berbeda. Oleh karena itu, proses penjumlahan vektor yang saling menguatkan ataupun saling melemahkan kemungkinan besar akan terjadi. Pathloss secara umum didefinisikan sebagai penurunan kuat medan secara menyeluruh sesuai bertambah jauhnya jarak antara pemancar dan penerima.Pada propagasi gelombang radio dalam ruang bebas, besarnya daya yang diterima oleh antenna penerima dapat dicari dengan berbagai persamaan, bergantung kepada jenis model propagasi yang kita gunakan. Model propagasi yang digunakan akan mempengaruhi hasil akhir perhitungan nilai pathloss(Kirana, Santoso, \& Puspitorini, 2010). 


\section{c) One Slope Model (1SM)}

One Slope Model (1SM) adalah cara paling mudah untuk mengukur level sinyal rata-rata pada suatu bangunan tanpa harus mengetahui layoutsuatu bangunan secara detail karena hanya bergantung pada jarak antara pemancar dan penerima. Model ini memiliki persamaan sebagai berikut(Válek, Zvánovec, \& Č, 2002):

$$
\mathrm{L}(\mathrm{d})=\operatorname{Lo}+10 \mathrm{n} \log (\mathrm{d})
$$

Keterangan:

$\boldsymbol{L o}=$ Rugi-rugi jalur dari Tx ke Rx terhadap refrensi jarak Ro pada propagasi free space (dalam $\mathrm{dB}$ ), Ro adalah referensi jarak Tx ke Rx yaitu 1 (satu) meter.

$\boldsymbol{n}=$ Power decay factor (eksponen dari rugi-rugi jalur)

$\boldsymbol{d}=$ Jarak dari pemancar ke penerima $(\mathrm{m})$

Pada persamaan 1 komponen $\boldsymbol{L O}$ dan $\boldsymbol{n}$ adalah parameter utama dari suatu bangunan yang akan diukur. Sebagai contoh dapat dilihat pada Tabel 1 yang nilainya diambil dari beberapa referensi(Zvanovec et al., 2003). Nilai $\boldsymbol{n}$ akan sangat dipengaruhi oleh jenis suatu bangunan dan keadaan lingkungan bagian dalam suatu bangunan. Jelas hal ini merupakan hal yang utama dalam menentukan cakupan sinyal.

Tabel 1. Parameter One Slope Model (1SM)

\begin{tabular}{cccl}
\hline \hline Frequency $(\mathbf{G H z})$ & Lo $(\mathbf{d B})$ & $\mathbf{n}(-)$ & \multicolumn{1}{c}{ Comment } \\
\hline 1.8 & 33.3 & 4.0 & Office \\
1.8 & 37.5 & 2.0 & Open space \\
1.8 & 39.2 & 1.4 & Corridor \\
1.9 & 38.0 & 3.5 & Office building \\
1.9 & 38.0 & 2.0 & Passage \\
1.9 & 38.0 & 1.3 & Corridor \\
2.45 & 40.2 & 4.2 & Office building \\
2.45 & 40.2 & 1.2 & Corridor \\
2.45 & 40.0 & 3.5 & Office building \\
2.5 & 40.0 & 3.7 & Office building \\
5.0 & 46.4 & 3.5 & Office building \\
5.25 & 46.8 & 4.6 & Office building \\
\hline \hline
\end{tabular}

\section{d) Link Budget}

Untuk mengetahui seberapa besar daya yang diterima di sisi penerima, digunakan perhitungan link budget. Persamaan link budget adalah sebagai berikut(Wanto, Hardinata, Silaban, \& Saputra, 2017):

Keterangan:

$$
P_{R}=P_{T}+G_{T}+G_{R}-L_{L P}
$$

$P_{R}=$ daya terima $(\mathrm{dBm})$

$P_{T}=$ daya pancar perangkat yang nilainya diperoleh dari spesifikasi perangkat yang diukur $(\mathrm{dBm})$

$G_{T}=$ gain antenna pemancar yang nilainya diperoleh dari spesifikasi perangkat yang diukur (dBm)

$G_{R}=$ gain antenna penerima yang nilainya diperoleh dari spesifikasi perangkat yang digunakan untuk mengukur $(\mathrm{dBm})$

$L_{L P}=$ nilai pathloss dari hasil perhitungan menggunakan 1SM

\section{e) Kuat Sinyal}

Cakupan area (coverage area) pada jaringan WLAN dilihat berdasarkan cakupan area yang dapat dijangkau oleh sinyal Wi-Fi. Semakin jauh pengguna dari coverage area maka sinyal yang didapatkan akan semakin sedikit/kecil. Coverage area akan menentukan kekuatan sinyal yang diterima oleh pengguna. Dengan melihat coverage area dari sebuah perangkat WLAN, maka dapat ditentukan tata letak penempatan AP yang tepat sehingga mengurangi adanya blank spot area.Satuan kekuatan sinyal jaringan WLAN ditunjukkan dalam satuan $\mathrm{dBm}$, dengan rentang kuat sinyal berada di antara -10dBm sampai kurang lebih - 
99dBm. Semakin mendekati angka positif, maka sinyal akan semakin kuat. Tabel 2 menunjukkan kategori kekuatan sinyal berdasarkan standar wireless adapter versi Cisco(Sirait, 2017).

Tabel 2. Kategori Kekuatan Sinyal Wi-Fi

\begin{tabular}{lll}
\hline \hline Category & Range & Percentage \\
\hline Excellent & -57 to $-10 \mathrm{dBm}$ & $75-100 \%$ \\
Good & -75 to $-58 \mathrm{dBm}$ & $40-74 \%$ \\
Fair & -85 to $-76 \mathrm{dBm}$ & $20-39 \%$ \\
Poor & -95 to $-86 \mathrm{dBm}$ & $0-19 \%$ \\
\hline \hline
\end{tabular}

\section{HASIL DAN PEMBAHASAN}

\section{a) Lokasi Penelitian}

Penelitian ini dilakukan untuk menganalisis performasi sistem propagasi indoor jaringan WLAN yang terdapat pada gedung STMIK Asia Malang. Berikut ini merupakan denah ruangan pada gedung STMIK Asia Malang.

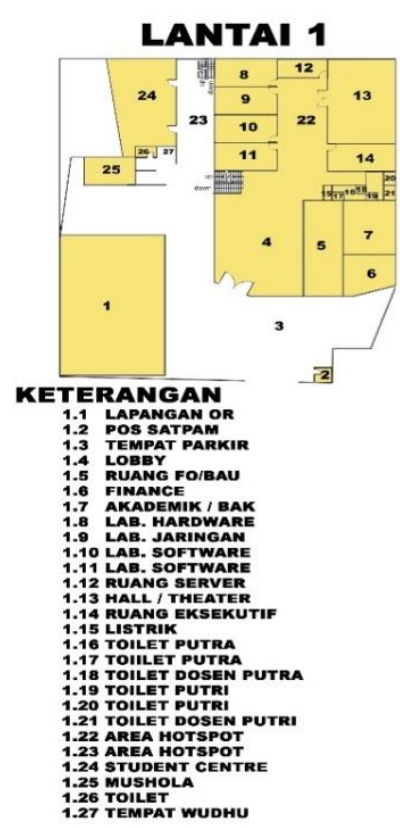

\section{BENAH STMIK ASIA MALANG}
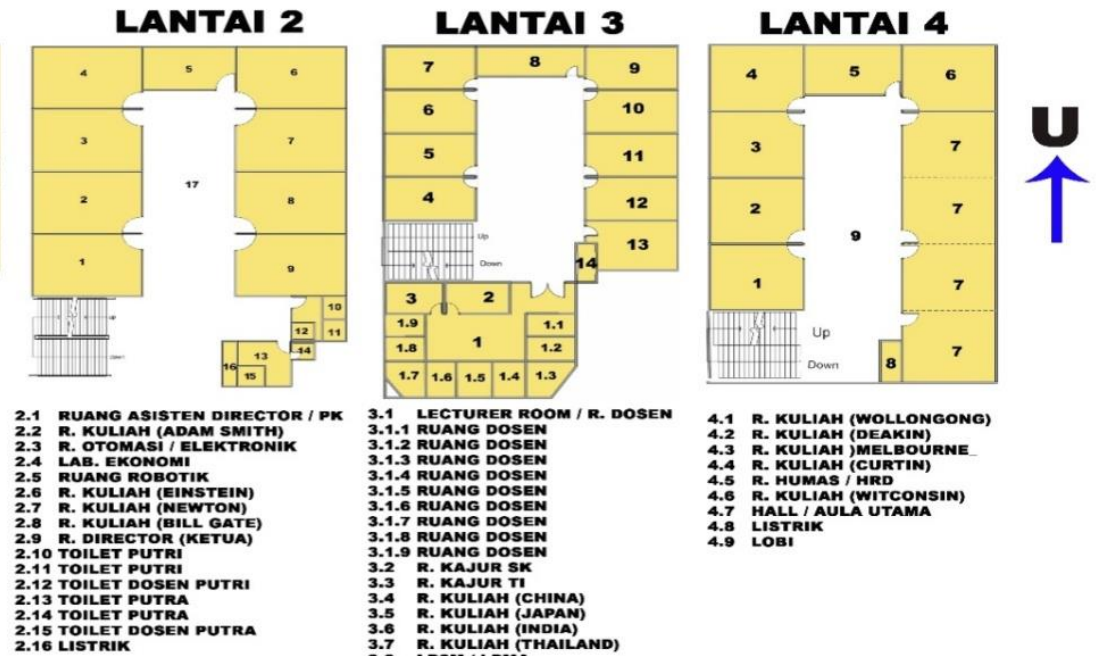

Gambar 1. Denah Gedung Kampus STMIK Asia Malang

Gambar 1 menunjukkan denah gedung kampus STMIK Asia Malang yang terdiri atas 4 lantai, dimana terlihat bahwa masing-masing lantai gedung memiliki ruangan-ruangan yang digunakan sebagai tempat perkuliahan dan bagian luar ruangan yang berbentuk koridor. Di setiap lantai terdapat AP yang digunakan sebagai media hotspot bagi seluruh civitas akademika, yang diletakkan pada bagian tengah atas koridor gedung. Berikut ini merupakan spesifikasi AP yang digunakan pada setiap lantai gedung, yang akan diukur sistem propagasinya dalam penelitian ini.

Tabel 3. Spesifikasi Perangkat yang Diukur(Ubiquiti Networks, 2011)

\begin{tabular}{lll}
\hline \hline Jenis Perangkat & Parameter & Nilai \\
\hline UniFi AP Long-Range & Operating Band & $2.4 \mathrm{GHz}$ \\
& Gain Antenna & $3 \mathrm{dBi}$ \\
& Maximum TX Power & $27 \mathrm{dBm}$ \\
& Line loss & $0,5 \mathrm{~dB}$ \\
& Fading margin WLAN & $10 \mathrm{~dB}$ \\
\hline
\end{tabular}




\section{b) Pengukuran Site Survey}

Tahapan penelitian yang pertama adalah melalui pendekatan site survey, yakni pendekatan yang dilakukan dengan cara melakukan pengukuran secara langsung di lapangan(Zvanovec et al., 2003).Tujuan utama dari pendekatan iniadalah untuk mendapatkan informasi yang cukup mengenai jumlah dan penempatan access point (AP) yang saat ini diaplikasikan pada gedung kampus STMIK Asia Malang. Pendekatan site survey dilakukan dengan menggunakan bantuan perangkat lunak inSIDDER yang diinstall pada sebuah netbook yang built-in dengan wireless Ethernet adapter, untuk mengukur kuat sinyal (signal strength-SS) dan menghitung rasio perbandingan kuat sinyal yang diterima dengan derau/gangguan di sekitar perangkat. Tabel 4 menunjukkan spesifikasi perangkat yang digunakan untuk mengukur performansi perangkat WLAN.

Tabel 4. Spesifikasi Perangkat yang Digunakan untuk Mengukur

\begin{tabular}{lll}
\hline \hline Jenis Perangkat & Parameter & Nilai \\
\hline Netbook ASUS X201EP & Processor & Intel(R) Celeron(R) CPU 847 @ \\
& & $1.10 \mathrm{GHz}$ (2 CPUs), 1.1GHz \\
& Memory & 4096MB RAM \\
& Operating System & Windows 7 Ultimate 64-bit (6.1, Build \\
& 7601) Service Pack 1 \\
& Wireless adapter & Qualcomm Atheros AR9485 Wireless \\
& Network Adapter \\
& Gain antenna & 0 dBi \\
\hline \hline
\end{tabular}

Pengukuran ini dilakukan secara berulang-ulang pada jarak tertentu dengan menggunakan metode regresi(Puspitasari \& Pulungan, 2015), yaitu dengan cara memilih lokasi di sekitar AP dengan jarak $d$, seperti yang terlihat pada Gambar 2.

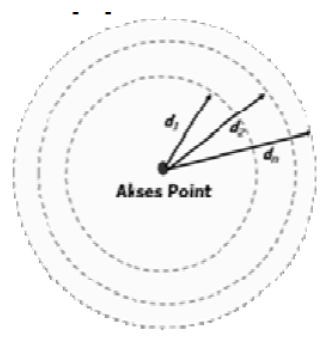

Gambar 2. Teknik Pengukuran Regresi

Jarak $d$ merupakan jarak pengukuran optimalnya sebesar $2 \lambda$ ( $\lambda$ adalah panjang gelombang radio, yang didapatkan dari perhitungan kecepatan gelombang elektromagnetik $3.10^{8} \mathrm{~m} / \mathrm{s}$ dibagi dengan frekuensi Wi-Fi 2.4GHz). Berikut ini merupakan perhitungan jarak minimal pengukuran dari AP ke perangkat penerima(Angela, 2014):

$$
d=2 \times \frac{3 \times 10^{8}}{2.4}=0,125 \mathrm{~m}
$$

Berdasarkan perhitungan di atas, didapatkan jarak minimal pengukuran adalah sebesar 0,125m. Namun dalam praktiknya, tidak memungkinkan dilakukan pengukuran pada jarak tersebut, sehingga dipilih jarak pengukuran setiap $1 \mathrm{~m}$ dimulai dari jarak $1 \mathrm{~m}$ antara AP dan netbook pengukur. Berdasarkan Gambar 2, setelah ditentukan jarak pengukuran, maka selanjutnya daerah pengukuran dibagi menjadi beberapa radius dengan jari-jari $R_{l}=1.0 \mathrm{~m}, R_{2}=2.0 \mathrm{~m}, R_{3}=3.0 \mathrm{~m}$, dan seterusnya. Di setiap radius yang telah ditentukan, dipilih 5 titik untuk dilakukan pengukuran dan dihitung rata-ratanya. Pengukuran ini dilakukan pada 2 jenis propagasi, yaitu propagasi Line of Sight (LOS) dan propagasi Non Line of Sight (NLOS). Banyaknya sampel 
pengukuran sesuai dengan referensi ideal sampel sebanyak 36 sampel untuk setiap titik pengukuran (perangkat) agar mendapat interval tingkat keyakinan sebesar 90\%(Angela, 2014). Pengukuran pada penelitian ini dibuat mendekati jumlah sampel ideal, yaitu sebanyak 23-28 titik pengukuran. Pengukuran dilaksanakan pada saat kondisi aktivitas akademika off (libur perkuliahan), untuk mendapatkan hasil pengukuran yang optimal.

\section{c) Perhitungan Propagasi Menggunakan 1SM}

Model propagasi indoor One Slope Model (1SM) digunakan untuk mengukur level sinyal rata-rata secara teoritis, dengan berpedoman pada parameter yang digunakan pada 1SM (Tabel 1). Pengukuran dengan menggunakan 1SM dilakukan dengan cara menghitung propagasi antara pemancar dan penerima, tanpa memperhatikan faktor lain (barrier), seperti layout bangunan, ketebalan tembok, pemantulan yang disebabkan oleh kaca maupun penghalang lainnya.

Perhitungan 1SM dilakukan untuk mencari nilai pathloss dari setiap perangkat dengan jarak pengukuran yang digunakan sama dengan pengukuran site survey yang telah dilakukan sebelumya, yaitu sebanyak 23-28 titik pengukuran, baik pada propagasi LOS maupun NLOS. Perhitungan pathloss menggunakan Persamaan (1), untuk selanjutnya menghitung nilai link budget untuk mengetahui seberapa besar daya yang diterima di sisi penerima. Parameter yang digunakan untuk melakukan perhitungan pathloss dan link budget tertera pada Tabel 5.

Tabel 5. Parameter Perhitungan 1SM dan Link Budget

\begin{tabular}{|c|c|c|c|}
\hline No. & Parameter & Nilai & Keterangan \\
\hline 1. & $f$ & $2.4 \mathrm{GHz}$ & Frekuensi perangkat WLAN yang digunakan \\
\hline \multirow[t]{2}{*}{2.} & $L_{0}$ & 40.0 & Rugi-rugi jalur dari Tx ke Rx (Office Building) \\
\hline & & 40.2 & Rugi-rugi jalur dari Tx ke Rx (Corridor) \\
\hline \multirow[t]{2}{*}{3.} & $n$ & 3.5 & Power decay factor (Office Building) \\
\hline & & 1.2 & Power decay factor (Corridor) \\
\hline 4. & $P_{T}$ & $27 \mathrm{dBm}$ & $\begin{array}{l}\text { Daya pancar perangkat yang diukur (UniFi AP } \\
\text { Long-Range) }\end{array}$ \\
\hline 5. & $G_{T}$ & $3 \mathrm{dBi}$ & $\begin{array}{l}\text { Gain antena perangkat yang diukur (UniFi AP } \\
\text { Long-Range) }\end{array}$ \\
\hline 6. & $G_{R}$ & $0 \mathrm{dBi}$ & $\begin{array}{l}\text { Gain antena perangkat yang digunakan untuk } \\
\text { mengukur (Netbook ASUS X201EP) } \\
\text { menggunakan software inSIDDER }\end{array}$ \\
\hline 7. & $L_{L P}$ & & $\begin{array}{l}\text { Nilai pathloss dari hasil perhitungan } \\
\text { menggunakan } 1 \mathrm{SM}\end{array}$ \\
\hline
\end{tabular}

Hasil perhitungan propagasi dengan menggunakan 1SM akan digunakan sebagai bahan perbandingan dengan hasil pengukuran site survey yang dilakukan di lapangan. Tabel 6 menunjukkan sampel hasil perhitungan teoritis menggunakan model propagasi 1SM dan link budget untuk mengetahui hasil daya yang diterima oleh user yang terhubung dengan perangkat WLAN pada lantai 3 di gedung kampus STMIK Asia Malang. 
Tabel 6. Perhitungan Nilai Pathloss dan Link Budget untuk Lantai 3

\begin{tabular}{|c|c|c|c|c|c|c|}
\hline Jenis Propagasi & $d(\mathbf{m})$ & AVG SS (dBm) & $L_{0}$ & $n$ & $L_{L P}(\mathrm{dBm})$ & Link Budget (dBm) \\
\hline \multirow[t]{12}{*}{ LOS } & 1.0 & -64 & 40.2 & 1.2 & 40.2 & -10.2 \\
\hline & 2.0 & -59 & 40.2 & 1.2 & 43.8123 & -13.8123 \\
\hline & 3.0 & -62.4 & 40.2 & 1.2 & 45.9255 & -15.9255 \\
\hline & 4.0 & -60.2 & 40.2 & 1.2 & 47.4247 & -17.4247 \\
\hline & 5.0 & -57.8 & 40.2 & 1.2 & 48.5876 & -18.5876 \\
\hline & 6.0 & -64.4 & 40.2 & 1.2 & 49.5378 & -19.5378 \\
\hline & 7.0 & -61.4 & 40.2 & 1.2 & 50.3412 & -20.3412 \\
\hline & 8.0 & -61 & 40.2 & 1.2 & 51.0371 & -21.0371 \\
\hline & 9.0 & -63.8 & 40.2 & 1.2 & 51.6509 & -21.6509 \\
\hline & 10.0 & -56.6 & 40.2 & 1.2 & 52.2 & -22.2 \\
\hline & 11.0 & -58.6 & 40.2 & 1.2 & 52.6967 & -22.6967 \\
\hline & 12.0 & -62.6 & 40.2 & 1.2 & 53.1501 & -23.1501 \\
\hline \multirow[t]{16}{*}{ NLOS } & 3.6056 & -69.4 & 40 & 3.5 & 59.4940 & -29.4940 \\
\hline & 4.2426 & -71.2 & 40 & 3.5 & 61.9673 & -31.9673 \\
\hline & 5.0 & -65 & 40 & 3.5 & 64.4640 & -34.4640 \\
\hline & 5.831 & -71.4 & 40 & 3.5 & 66.8009 & -36.8009 \\
\hline & 6.7082 & -75 & 40 & 3.5 & 68.9312 & -38.9312 \\
\hline & 9.2195 & -65.2 & 40 & 3.5 & 73.7648 & -43.7648 \\
\hline & 9.4868 & -70.6 & 40 & 3.5 & 74.1992 & -44.1992 \\
\hline & 9.8489 & -71.6 & 40 & 3.5 & 74.7685 & -44.7685 \\
\hline & 10.296 & -69.6 & 40 & 3.5 & 75.4429 & -45.4429 \\
\hline & 10.817 & -66 & 40 & 3.5 & 76.1933 & -46.1933 \\
\hline & 11.402 & -213.2 & 40 & 3.5 & 76.9940 & -46.9940 \\
\hline & 12.042 & -78.4 & 40 & 3.5 & 77.8239 & -47.8239 \\
\hline & 10.198 & -69.6 & 40 & 3.5 & 75.2981 & -45.2981 \\
\hline & 10.440 & -69.8 & 40 & 3.5 & 75.6550 & -45.6550 \\
\hline & 10.770 & -69.4 & 40 & 3.5 & 76.1280 & -46.1280 \\
\hline & 11.180 & -73.6 & 40 & 3.5 & 76.6959 & -46.6959 \\
\hline
\end{tabular}

\section{d) Analisis Penempatan Access Point}

Analisis dilakukan dengan membandingkan antara hasil pengukuran di lapangan dan melakukan perhitungan teoritis menggunakan 1SM. Hasil yang dibandingkan adalah level daya yang diterima oleh pengguna, yang diwakilkan melalui nilai kuat sinyal pada lapangan dan nilai link budget dengan menggunakan 1SM. Untuk mendapatkan hasil yang valid, maka perhitungan dan analisis perbandingan dilakukan dengan menggunakan jarak (d) pengukuran yang sama dan lokasi yang sama. Hasil perbandingan ditunjukkan dalam bentuk grafik pada Gambar 3 - Gambar 6. 

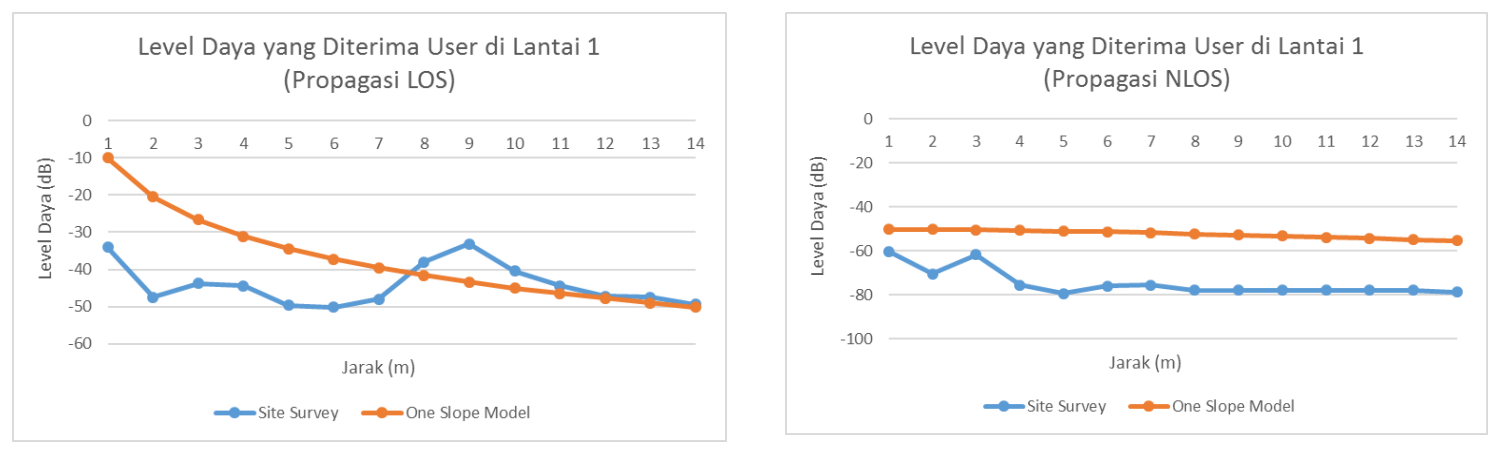

Gambar 2. Komparasi Level Daya di Lantai 1 Gedung STMIK Asia Malang

Perangkat WLAN yang digunakan di lantai 1 gedung kampus STMIK Asia Malang terletak di depan ruang Salesmanship, dengan tipe perangkat Unifi AP-Long Range, yang diletakkan menghadap ke arah basement gedung. Terlihat hasil pengukuran kuat sinyal pada propagasi LOS masih berada di rentang $-34 \mathrm{~dB}$ sampai dengan $-50.2 \mathrm{~dB}$, yang mengkisarkan prosentase kuat sinyal berada di angka 75-100\% (berdasarkan kualifikasi prosentase kuat sinyal pada Tabel 2). Sebaliknya, hasil pengukuran kuat sinyal yang didapatkan pada propagasi NLOS berada di rentang $-60.2 \mathrm{~dB}$ sampai dengan $-79.4 \mathrm{~dB}$, yang mengkisarkan prosentase kuat sinyal berada di angka 20-74\% saja. Menunjukkan bahwa penempatan AP hanya dapat dijangkau pada propagasi LOS saja, dan keberadaan barrier sangat mempengaruhi kuat sinyal yang didapatkan oleh pengguna.
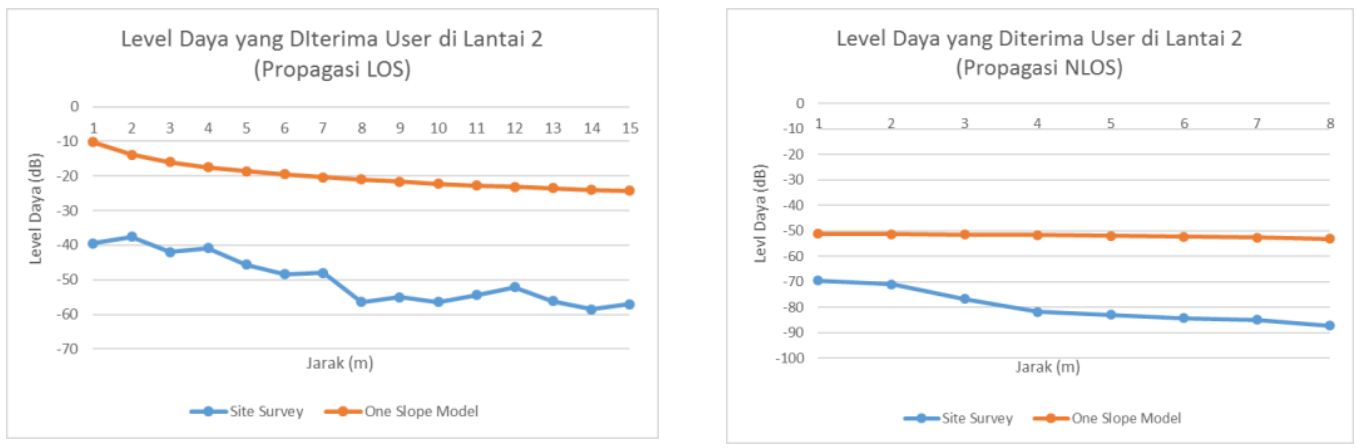

Gambar 3. Komparasi Level Daya di Lantai 2 Gedung STMIK Asia Malang

Perangkat WLAN yang digunakan di lantai 2 gedung kampus STMIK Asia Malang terletak di bagian tengah koridor gedung, dengan tipe perangkat Unifi AP-Long Range, yang diletakkan di langit-langit ruangan. Terlihat hasil pengukuran kuat sinyal pada propagasi LOS masih berada di rentang -37.6dB sampai dengan $-58.6 \mathrm{~dB}$, yang mengkisarkan prosentase kuat sinyal berada di angka $75 \%-100 \%$. Sebaliknya, hasil pengukuran kuat sinyal yang didapatkan pada propagasi NLOS berada di rentang -69.6dB sampai dengan 87.2dB, yang mengkisarkan prosentase kuat sinyal berada di angka 0-39\%. Menunjukkan bahwa penempatan AP hanya dapat dijangkau pada propagasi LOS saja, dan sinyal AP tidak dapat dijangkau dari dalam ruangan (propagasi NLOS). 

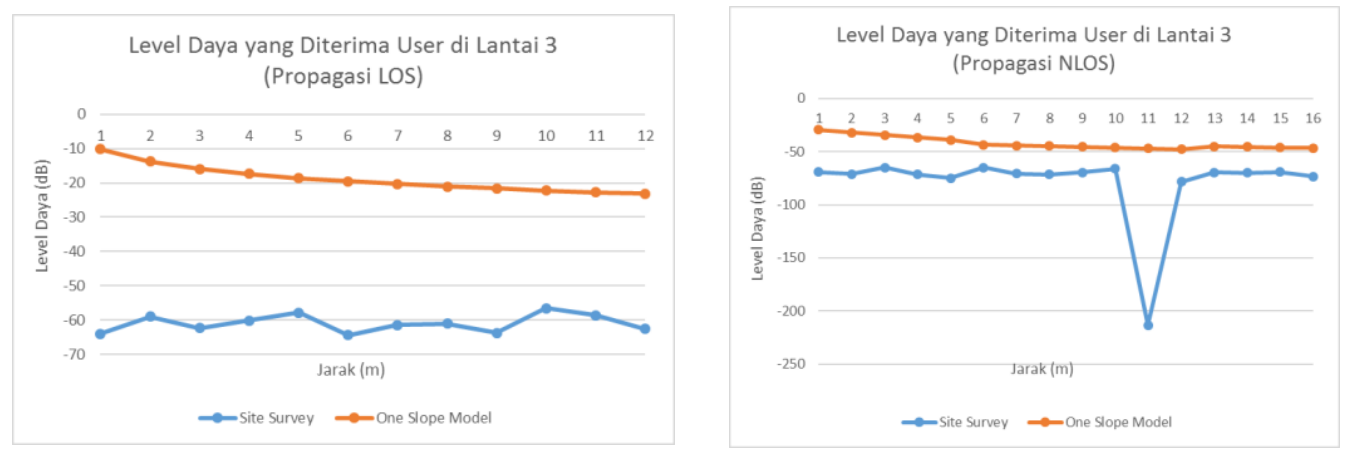

Gambar 4. Komparasi Level Daya di Lantai 3 Gedung STMIK Asia Malang

Lantai 3 gedung STMIK Asia Malang merupakan area utama perkuliahan yang diadakan di STMIK Asia Malang, karena hampir 80\% dari aktivitas perkuliahan dilaksanakan di ruangan-ruangan kelas pada lantai ini. Perangkat WLAN yang digunakan di lantai 3 gedung kampus STMIK Asia Malang terletak di bagian tengah koridor gedung, dengan tipe perangkat Unifi AP-Long Range, yang diletakkan di langit-langit ruangan. Terlihat hasil pengukuran kuat sinyal pada propagasi LOS memiliki nilai yang lebih buruk dibandingkan lantai 1 dan lantai 2, yaitu berada di rentang $-56.6 \mathrm{~dB}$ sampai dengan $-64.4 \mathrm{~dB}$, yang mengkisarkan prosentase kuat sinyal berada di angka 40-74\%. Hasil pengukuran kuat sinyal yang didapatkan pada propagasi NLOS menunjukkan hasil yang lebih buruk, yakni berada di rentang -65.2dB sampai dengan -213.2dB, yang mengkisarkan prosentase kuat sinyal berada di angka 0-74\%. Banyaknya ruangan kelas di lantai 3 ini mengakibatkan banyaknya sinyal yang mengalami refleksi dan difraksi, sehingga menyebabkan pengguna tidak dapat mengakses AP dari dalam ruangan, apabila ruangan ditutup, karena sinyal terserap pada temboktembok pembatas ruangan.
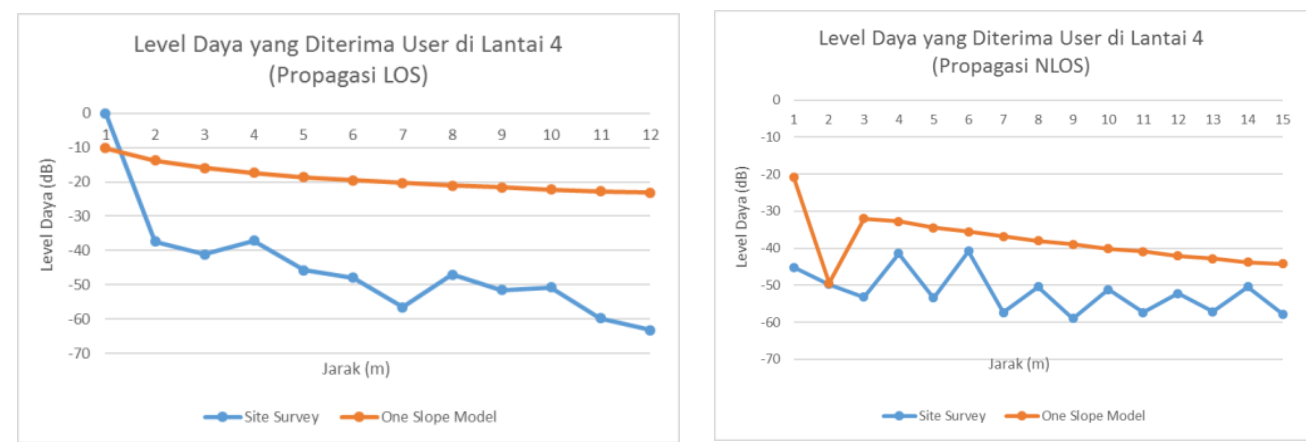

Gambar 5. Komparasi Level Daya di Lantai 4 Gedung STMIK Asia Malang

Lantai 4 gedung STMIK Asia Malang merupakan area utama kedua perkuliahan yang diadakan di STMIK Asia Malang, karena hampir 80\% dari aktivitas perkuliahan dilaksanakan di ruangan-ruangan kelas pada lantai ini, selanjutnya pada lantai ini juga terdapat ruangan yang tersekat-sekat yang biasanya digunakan untuk kuliah tamu. Perangkat WLAN yang digunakan di lantai 4 gedung kampus STMIK Asia Malang juga terletak di bagian tengah koridor gedung, dengan tipe perangkat Unifi AP-Long Range, yang diletakkan di langit-langit ruangan. Terlihat hasil pengukuran kuat sinyal pada propagasi LOS memiliki nilai yang sedikit lebih baik dibandingkan lantai 3, yaitu berada di rentang -41.2dB sampai dengan $-3.2 \mathrm{~dB}$, yang mengkisarkan prosentase kuat sinyal berada di angka $75-100 \%$. Hasil pengukuran kuat sinyal yang didapatkan pada propagasi NLOS menunjukkan hasil yang lebih baik, yakni berada di rentang $-41.4 \mathrm{~dB}$ sampai dengan $-59 \mathrm{~dB}$, yang mengkisarkan prosentase kuat sinyal berada di angka $75-100 \%$. Hasil kuat sinyal yang diterima antara propagasi LOS dan propagasi NLOS tidak mengalami perbedaan yang cukup signifikan karena $40 \%$ sekat 
ruangan yang digunakan pada area gedung ini berupa triplek, sehingga sinyal tidak mengalami penyerapan secara menyeluruh.

\section{KESIMPULAN}

Penelitian ini bertujuan untuk menganalisis penempatan access point (AP) pada jaringan WLAN STMIK Asia Malang, yang berdampak terhadap level daya atau kuat sinyal yang diterima oleh pengguna. Pendekatan pertama melalui site survey, dengan tujuan yakni mendapatkan informasi yang cukup mengenai jumlah dan penempatan AP yang saat ini diaplikasikan pada gedung kampus STMIK Asia Malang. Hasil dari walktest ini akan digunakan sebagai parameter untuk perhitungan teoritis menggunakan model propagasi One Slope Model (1SM).

Hasil pengukuran menunjukkan bahwa semakin jauh jarak antara user dan AP, maka kuat sinyal yang diterima juga akan semakin kecil (dibuktikan dengan nilai kuat sinyal yang memiliki angka negative semakin besar atau menjauhi angka positif). Terdapat perbedaan nilai antara pengukuran di lapangan dan perhitungan dengan menggunakan 1SM. Hasil perhitungan yang berbeda disebabkan karena model propagasi 1SM hanya berdasarkan jarak antara perangkat dan penerima saja, tanpa memperhatikan keberadaan barrier di sekitar perangkat.

Berdasarkan perhitungan 1SM, didapatkan jarak optimal untuk penempatan AP tidak lebih dari $13 \mathrm{~m}$ pada propagasi LOS (rentang kuat sinyal -10dB sampai dengan -20dB, pada area koridor gedung) dan jarak 6 $\mathrm{m}$ pada propagasi NLOS (rentang kuat sinyal -40dB sampai dengan -50dB, pada area ruangan perkuliahan). Hasil dari analisis di atas membuktikan bahwa keberadaan barrier mempengaruhi kekuatan sinyal yang diterima oleh user, sehingga penempatan perangkat WLAN, dalam hal ini AP perlu diperhatikan. Selanjutnya, diperlukan penelitian lanjutan yang dapat menghitung karakteristik sistem propagasi indoor yang memperhatikan keberadaan barrier, dengan tujuan untuk mendapatkan coverage area yang maksimal untuk jaringan WLAN di gedung kampus pusat STMIK Asia Malang.

\section{DAFTAR RUJUKAN}

Angela, D. (2014). Optimasi Jaringan Wireless LAN (Studi Kasus Di Kampus ITHB Bandung), (80).

Kirana, N. W., Santoso, T. B., \& Puspitorini, O. (2010). Desain Penempatan Antena Wi-Fi 2 , 4 Ghz di Hall Gedung Baru PENS-ITS dengan Menggunakan Sistem C-MIMO. Surabaya.

Meng, W., He, Y., Deng, Z., \& Li, C. (2012). Optimized Access Points Deployment for WLAN Indoor Positioning System. IEEE Wireless Communications and Networking Conference, WCNC, 2457-2461. https://doi.org/10.1109/WCNC.2012.6214209

Puspitasari, N. F., \& Pulungan, R. (2015). Optimisasi Penempatan Posisi Access Point Pada Jaringan Wi-Fi Menggunakan Metode Simulated Annealing. Citec Journal, 2(1), 51-64.

Sirait, R. (2017). Optimasi Penempatan Access Point pada Jaringan Wi-Fi di Universitas Budi Luhur. Arsitron, 8(1).

Ubiquiti Networks. (2011). UniFi AP DataSheet. Retrieved July 31, 2018, from https://dl.ubnt.com/datasheets/unifi/UniFi_AP_DS.pdf

Válek, M., Zvánovec, S., \& Č, P. P. (2002). Indoor Propagation Measurement for Wireless Systems Operating in $2.45 \mathrm{GHz}$ ISM Band. Radioengineering, 11(4), 48-52.

Wanto, A., Hardinata, J. T., Silaban, H. F., \& Saputra, W. (2017). Analisis Dan Pemodelan Posisi Access Point Pada Jaringan Wi-Fi Menggunakan Metode Simulate Annealing. Jurnal Sains Komputer Dan Informatika (J-SAKTI), (1), 134-143.

Zrno, D., Simunic, D., \& Roboz, M. (2004). Indoor propagation prediction software and WLAN measurements at $2.4 \mathrm{GHz}$. International Conference on Software, Telecommunications and Computer Networks.

Zvanovec, S., Pechac, P., \& Klepal, M. (2003). Wireless LAN networks design: site survey or propagation modeling? Radioengineering, 12(4), 42-49. 